\title{
Effect of Corporate Governance, Firm Characteristic, Disclosure of Corporate Social Responsibility (CSR) on Firm Value
}

\author{
Rahimah Bawai ${ }^{*}$, Hermala Kusumadewi ${ }^{2}$ \\ ${ }^{12}$ Akademi Akuntansi YKPN Yogyakarta, Indonesia

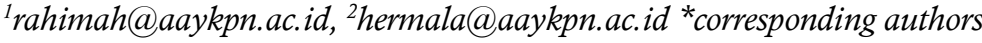

\begin{abstract}
This study aims to determine the effect of corporate governance, firm characteristics, disclosure of corporate social responsibility (CSR) on firm value. It analyzes the firms which became the participants of the 2014 Sustainability Report Award. Corporate governance is proxied by the proportion of independent commissioners, while firm characteristic is proxied through the age of the firm. Meanwhile, the disclosure of corporate social responsibility (CSR) in the sustainability report is stated in the Corporate Social Responsibility Index (CSRI). The firm value was calculated using the Tobins' $\mathrm{Q}$ formula. The hypothesis was tested using linear regression. The test results show corporate governance and firm characteristics have a positive effect on firm value. Meanwhile, corporate social responsibility (CSR) disclosure has a positive but insignificant effect on the dependent variable. If all independent variables are tested simultaneously, all three variables have a positive effect. However, disclosure of corporate social responsibility (CSR) has no significant effect.
\end{abstract}

Keywords: corporate governance, firm characteristics, corporate social responsibility (CSR), firm value, sustainability report

\section{Pengaruh Corporate Governance, Karakteristik Perusahaan, Pengungkapan Corporate Social Responsibility (CSR) terhadap Nilai Perusahaan}

\begin{abstract}
Abstrak
Penelitian ini untuk mengetahui pengaruh corporate governance, karakteristik perusahaan, pengungkapan corporate social responsibility (CSR) terhadap nilai perusahaan. Periode penelitian tahun 2014-2018 yang merupakan perusahaan peserta Sustainability Report Award 2014. Corporate governance diproksi dengan proporsi dewan komisaris independen. Kemudian karakteristik perusahaan diproksi melalui umur perusahaan yang dihitung dari tahun berdiri perusahaan dikurangi dengan tahun penelitian. Sedangkan pengungkapan corporate social responsibility (CSR) pada laporan sustainability report dinyatakan dalam Corporate Social Responsibility Index (CSRI) yang disyaratkan oleh Global Reporting Initiative (GRI). Variabel dependen nilai perusahaan dihitung menggunakan rumus tobins' $Q$. Pengambilan sampel menggunakan metode purposive sampling dengan jumlah sampel sebanyak 19 perusahaan. Pengujian hipotesis dengan regresi linear. Hasil pengujian menunjukkan corporate governance dan karakteristik perusahaan berpengaruh positif terhadap nilai perusahaan. Sedangkan pengungkapan corporate social responsibility (CSR) berpengaruh positif namun tidak signifikan. Jika seluruh variabel independen diuji secara bersamaan, ketiga variabel mempunyai pengaruh positif. Namun pengungkapan corporate social responsibility (CSR) tidak memiliki pengaruh yang siginifikan.
\end{abstract}

Kata kunci: corporate governance, karakteristik perusahaan, corporate social responsibility (CSR), nilai perusahaan, sustainability report.

\section{INTRODUCTION}

This study aims to analyze the effect of good corporate governance, firm characteristics, and disclosure of corporate social responsibility (CSR) on the firm value among the 
participants of the 2014 Sustainability Report Award (SRA). This research is motivated by the company's awareness of the increasingly high environmental conditions and the increasing number of companies that seem to be racing to engage in environmental preservation, especially around their own companies. The second motivation of this research is the fact that the standard on disclosure of corporate social responsibility (CSR) implementation reports has not been fully implemented. Some companies disclose corporate social responsibility (CSR) reports in annual reports, but some have been separated in the sustainability report. The third motivation is related to the firm value that must be maintained and even improved in line with the demands of good corporate governance and the environment that must also be preserved. The firm value can be reflected in the share price of a company. Investors will monitor the share price of a company that goes public through transactions that take place on the stock exchange. The higher the share price, the higher the firm value.

The company's attention to the environment is one component of corporate social responsibility (CSR). It can be interpreted as a form of corporate accountability to its environment so that it can ultimately increase the firm value. The Law No. 40/2007 on Limited Liability Companies states the rules relating to the disclosure of corporate social responsibility (CSR) in Indonesia are as follows:

1. Section Two of Article 66 paragraph 6 reads "The annual report shall contain at least: financial statements, reports on the Company's activities, reports on the implementation of social and environmental responsibilities, details of problems arising during the financial year affecting the Company's business activities, reports on supervisory duties that have been carried out by the Board of Commissioners, salaries, and allowances of members of the Board of Directors, and salaries of the Board of Commissioners."

2. Chapter V of Social and Environmental Responsibility Article 74 paragraph 1 reads "Companies conducting their business activities in the field and/or related to natural resources are obliged to carry out social and environmental responsibilities."

In addition to environmental issues, good corporate governance is also a must-have for companies to achieve good corporate value. The implementation of good corporate governance is expected to increase the firm value over time. Moreover, good corporate governance can also dampen various interests to provide benefits for the company as a whole. It is common for the management has different interests with the shareholders, resulting in a conflict called agency conflict. In the concept of theory of the firm (Jensen \& Meckling, 1976), agency conflict will cause the failure to achieve the company's financial objectives, i.e. increasing the value of the company by maximizing the wealth of shareholders. Managers put personal interests first, on the contrary shareholders do not like the personal interests of the manager because what the manager does will increase the cost to the company. Consequently, it will decrease the company's profits and affect the share price thereby lowering the firm value (Jensen \& Meckling, 1976).

Wibisono (2007) states that the implementation of corporate social responsibility (CSR) is generally influenced by factors related to the commitment of leaders, the 
application of good corporate governance, the size of the company, maturity (age) of the company, regulation, and taxation system. Indicators that become the benchmark of a company to implement corporate social responsibility (CSR) include labor, human rights, social or community, and products. The implementation of corporate social responsibility (CSR) disclosure has no direct side effects on financial performance or firm value. Disclosure of corporate social responsibility (CSR) is a future investment that will bring better firm values in the eyes of investors. Research conducted by Wulandari et al., (2016) has revealed that CSR implementation may promote some positive impacts such as it can build brand positioning, boost sales, expand market share, increase employee loyalty, and increase the company's attractivity in the eyes of investors.

Firm characteristic is a distinctive characteristic owned by merely one company. Companies that have been established and developed for more than 10 years will certainly be very different from start-ups that have only been established for less than 5 years. Differences can be seen from the policies taken to good corporate governance or disclosure of environmental issues that have been made. The longer the company is established, the more mature it has become as well as having good corporate values. The excellent values of a corporate will reflect the welfare of the owner.

This study contributes to complement the literature on the firm value in which the company should always improve over time, especially if it is associated with environmental issues that should be more considered by the company in the disclosure of corporate social responsibility (CSR) in the sustainability report. Throughout the observations of researchers, there is currently only a few empirical researches conducted using sustainability reports. Most research on corporate social responsibility (CSR) disclosure tend to focus on annual reports only. This has also been proved by the lack of companies in Indonesia which disclose corporate social responsibility (CSR) in the sustainability report. In Financial Accounting Standards Statement (PSAK) No. 1 (Revised 2009) Paragraphs 8-12 on the components of the full financial statements implicitly advise the company to have a report which reviews the changing environment that the company operates presented separately from the company's financial statements. This sustainability report will be prepared with the global reporting initiative (GRI) standard guideline that has been developed since 1990 and is also separated from financial statements or annual reports.

Herawaty (2008) showed that corporate governance has a significant influence on the firm value with independent commissioner variables and institutional ownership. Moreover, Retno \& Priantinah (2012) found a significant positive effect of good corporate governance and corporate value which is in line with the previous research. Subsequently, the study also discovered that the disclosure of corporate social responsibility (CSR) has a positive but insignificant effect on the firm value. However, good corporate governance and disclosure of corporate social responsibility (CSR) will still have a positive effect on the firm value. Conversely, other researchers discovered that corporate social responsibility (CSR) has a significant positive effect on the firm value (Permanasari, 2010). Latupono \& Andayani (2015) also stated the same thing in which corporate social 
responsibility disclosure has a significant positive effect on the firm value, as well as the implementation of Good Corporate Governance (GCG) with managerial ownership proxy can strengthen the relationship between CSR and firm values.

Furthermore, C. D. Putri (2013) expressed a different opinion, where corporate governance that is proxied by the proportion of independent commissioners does not affect corporate social responsibility (CSR) disclosure whereas the firm characteristics as measured by the age of the company have a positive effect on the disclosure of corporate social responsibility (CSR). This is in line with research conducted by A. K. Putri et al. (2016) which stated that Corporate Social Responsibility disclosure does not affect the value of the company, but the firm value will be affected by CSR disclosure if moderated by the size of the company and a few commissioners. Moreover, Fauziah et al. (2016) took an LQ45 index company sample in the period 2009-2013, concluding that CSR disclosures have a negative influence on the financial performance and performance of the company's shares, in the sense that an investor in buying shares in companies included in the LQ45 index does not prioritize CSR aspects in their investment decision making. The results of previous studies that were inconsistent became a special interest for the authors.

Based on the previous studies on corporate governance, corporate social responsibility (CSR) disclosure, company characteristics and corporate values and theories related to disclosure (agency theory and signaling theory), researchers are looking for answers to the following research questions:

RQ1: Does a company that has good corporate governance, strong corporate characteristics, and discloses corporate social responsibility (CSR) in the sustainability report can have high corporate values?

Thus, the purpose of this research is to investigate the influence of corporate governance, corporate characteristics, corporate social responsibility (CSR) disclosure, and corporate values. To achieve this goal, the study uses a variety of proxies to describe several variables from previous research and refers to the Corporate Social Responsibility Index (CSRI) of the Global Reporting Initiative (GRI) following the prevailing provisions in Indonesia.

The theories used in this study include agency theory and signaling theory. Agency theory is defined as the relationship between the agent (company management) and the principal (business owner). The difference of interest between the two can be minimized by the existence of corporate governance as a mechanism that regulates and controls the company. da Silveira \& Barros (2011) examined the influence of corporate governance quality on the market values of 154 Brazilian companies listed on the stock exchange in 2002. The findings showed the influence of positive and significant corporate governance quality on the company's values. Subsequently, the research replicated by the authors also found the same results that good corporate governance has a positive effect on the firm values (Retno \& Priantinah, 2012). Rustiarini (2010) also shows the same results that corporate governance affects the values of the company

Furthermore, signaling theory suggests how a company should give signals to users of financial and non-financial statements. Disclosure of corporate social responsibility 
(CSR) can be used as a good news signal given by the management to the public that the company has good prospects in the future. Information about corporate social responsibility (CSR) can be disclosed in the annual report or separately through the sustainability report. Several studies were conducted to corroborate that opinion. Retno \& Priantinah (2012) found that the disclosure of corporate social responsibility (CSR) has no significant influence on the firm values. The same results were found in the study by Vira \& Wirakusuma (2019) stating that the disclosure of corporate social responsibility (CSR) negatively affects the firm values. Meanwhile, other research found that disclosure of corporate social responsibility (CSR) affects the firm values (Permanasari, 2010; Rustiarini, 2010).

The implementation of corporate social responsibility (CSR) disclosure in Indonesia that is still voluntary will be different according to the company's conditions. A longstanding company will manage information well so that it's most likely that the disclosure of corporate social responsibility (CSR) will be more. This is in line with research conducted by C. D. Putri (2013) and Untari (2011) indicating that firm characteristics calculated by the age of the company has a positive influence on corporate social responsibility (CSR) disclosure. Furthermore, Widianto (2011) found that there is a significant difference between the company's characteristics and the implementation of corporate governance between companies that make disclosures and do not disclose corporate social responsibility (CSR).

In the long run, the goal of a company is not only to maximize profit but also to optimize the firm values. The firm values will reflect the welfare of its owner. Companies that have strong characteristics have carried out a variety of business activities that can increase the firm values. The characteristic of the company is usually characteristically developed by the company for its benefit. Arilaha (2009), Ikhwandarti et al. (2010), Masrifa (2010) found evidence that the characteristics of the company can affect the firm values. The larger the size of the company or the longer the company operates and survives in the business world, investors will give a positive signal and a good response to the company's performance. Investors' interest in the company can lead to a continuous increase in the values of the company. High-profile companies will have more value in the eyes of investors.

Based on the conceptual framework above, the authors proposed the hypothesis as follows:

$\mathrm{H}_{1}$ : Good corporate governance will positively affect the company's values.

$\mathrm{H}_{2}$ : Characteristics of the Company will positively affect the values of the company

$\mathrm{H}_{3}$ : Disclosure of corporate social responsibility (CSR) in the sustainability report will positively affect the firm values.

$\mathrm{H}_{4}$ : Good corporate governance, corporate social responsibility (CSR) disclosure in the sustainability report, and company characteristics will positively affect the firm values 


\section{METHOD}

This study used quantitative research with purposive sampling technique. Subjects in this study included participants from the 2014 Sustainability Report Award. Subjects were selected based on the following criteria: (1) companies were go public companies listed in IDX from 2014-2018, and (2) companies published sustainability reports for the period of 2014-2018. Data were obtained from various sources, namely IDX, ICMD, company annual report, and sustainability report. The sample data consisted of 19 companies from 2014-2018, so that the total number of samples processed was 90. Data processing techniques used linear regression method with a significant rate of $1 \%$. The model developed in this study can be seen in Figure 1.

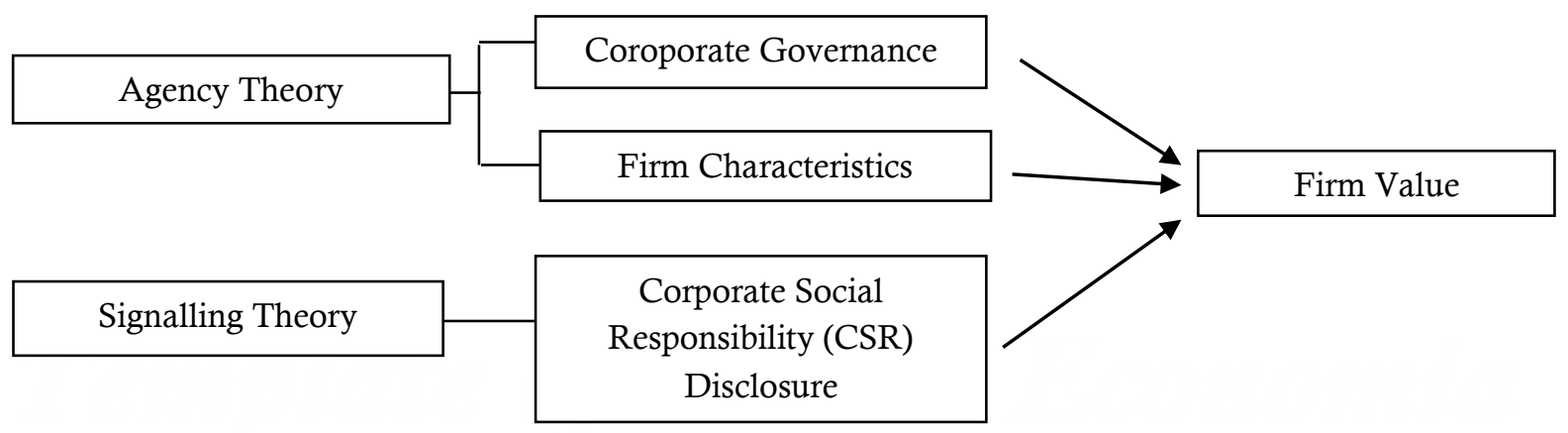

Figure 1: Research Conceptual Framework

The object in this study is the firm values, serving as a dependent variable. Firm value is the selling values of the company or the growing values for shareholders which is reflected in its stock market price. The higher the share price, the higher the firm values. To achieve high corporate values, shareholders usually hand over the management of the company to professionals who in this case serve as managers or commissioners. Murwaningsari et al. (2009) stated that the measurement of the firm values is formulated based on the Tobins' $Q$ formula as follows:

$$
\mathrm{Q}=\frac{\mathrm{EMV}+\mathrm{D}}{\mathrm{TA}}
$$

Where:

$\mathrm{Q} \quad=$ Firm Values

EMV = Market Value of Equity obtained from multiplying the closing share price at the end of the year with the number of shares outstanding at the end of the year

TA $=$ Total of all assets

$\mathrm{D} \quad=$ Total Book Value of Debt

The object of research as the independent variable is corporate governance. According to the Finance Committee on Corporate Governance in the book The Power of Good Corporate Governance: Teori dan Implementasi (Effendi, 2009), corporate governance is a process and structure used to direct and manage the company's business and activities towards increasing business growth and corporate accountability. Forum for Corporate Governance (FCGI) in its first publication used the Cadbury Committee definition, i.e. "a set of regulations regulating the relationship between shareholders, 
management (managers) of the company, creditors, governments, employees as well as other internal and external stakeholders relating to their rights and obligations, or in other words a system that regulates and controls the company" (Retno \& Priantinah, 2012). According to the General Guidelines of Good Corporate Governance Indonesia, GCG has the following principles: 1) transparency; 2) accountability; 3) responsibility; 4) independence; and 5) fairness and equality (Solihin, 2011).

The Board of Commissioners is generally responsible for carrying out supervision and providing advice to the board of directors and ensuring that the company has implemented good corporate governance under applicable rules. In the book entitled "Penerapan Good Corporate Governance: Mengesampingkan Hak-hak Istimewa Demi Kelangsungan Usaha" (Surya \& Yustiavandana, 2006) explains that the Independent Board of Commissioners is a commissioner who is not a member of management, majority shareholders, officials, or in other ways directly or indirectly related to the majority shareholder of a company that oversees the management of the company. The existence of the Independent Board of Commissioners has been regulated in the IDX regulations which require companies whose shares are listed in IDX to have an independent board of commissioners of at least $30 \%$ of all members of the Board of Commissioners (IDX Regulations dated on July 19, 2004).

Another object of research as the independent variable is the firm characteristics. Characteristics can be interpreted as special characteristics or distinctive traits that correspond to a particular character. Firm characteristics itself can be interpreted as special characteristics that become the sign of the company and become a differentiator with other companies. What can distinguish a company from another is the length of operation of a company. How long a company operates is calculated from its inception until now. The age of the company shows the ability of the company to survive and the amount of information that can be absorbed by the public. The longer the life of the company, the more information is obtained by the company to minimize certainty in the future (Sembiring, 2006).

According to The World Business Council for Sustainable Development (WBCSD), corporate social responsibility (CSR) is defined as a business commitment to contribute to sustainable economic development, through cooperation with employees and their representatives, their families, local communities, and the general public (Effendi, 2009). The principles related to corporate social responsibility (CSR) are accountability, transparency, ethical behavior, respect for stakeholders' interests, compliance with the law, respect for international norms of behavior, and enforcement of human rights. Disclosure of corporate social responsibility (CSR) is to present information deemed necessary regarding the implementation of corporate social responsibility (CSR) that has been for a period to meet and serve the needs of various parties who have different interests.

The company's corporate social responsibility (CSR) disclosure rate is measured based on guidelines issued by the Global Reporting Initiative (GRI) consisting of three main components of disclosure that show the impact of the company's activities on the 
economy, environment, and society. The three dimensions are then expanded into 6 dimensions, namely: economy, environment, labor practices, human rights, society, and product responsibilities. From the six dimensions, there are 34 constructs elaborated in 79 items.

This research also involves control variables, i.e. variables which are controlled to complement their cavalry relationships to better and obtain a complete empirical model. The function of the control variable is to prevent the result of the bias calculation. This study used two control variables, namely ROA and leverage (LEV). ROA is taken from each company's ICMD report while leverage is measured by dividing total liabilities by total assets. This control variable was used referring to previous research by Retno \& Priantinah (2012) replicated by the authors.

To determine the effect of independent variables on the firm values, the model is used as follows:

$\begin{array}{ll}\text { Value }_{\text {it }} & =\alpha_{i t}+\beta_{1} \mathrm{CG}_{\mathrm{it}}+\beta_{2} \mathrm{ROA}_{\mathrm{it}}+\beta_{3} \mathrm{LEV}_{\mathrm{it}}+\varepsilon_{\mathrm{it}} \\ \text { Value }_{\text {it }} & =\alpha_{\mathrm{it}}+\beta_{1} \mathrm{KR}_{\mathrm{it}}+\beta_{2} \mathrm{ROA}_{\mathrm{it}}+\beta_{3} \mathrm{LEV}_{\mathrm{it}}+\varepsilon_{\mathrm{it}} \\ \text { Value }_{\mathrm{it}} & =\alpha_{\mathrm{it}}+\beta_{1} \mathrm{CSR}_{\mathrm{it}}+\beta_{2} \mathrm{ROA}_{\mathrm{it}}+\beta_{3} \mathrm{LEV}_{\mathrm{it}}+\varepsilon_{\mathrm{it}} \\ \text { Valuei }_{\text {it }} & =\alpha_{\mathrm{it}}+\beta_{1} \mathrm{CG}_{\mathrm{it}}+\beta_{2} \mathrm{KR}_{\mathrm{it}}+\beta_{3} \mathrm{CSR}_{\mathrm{it}}+\beta_{4} \mathrm{ROA}_{\mathrm{it}}+\beta_{5} \mathrm{LEV}_{\mathrm{it}}+\varepsilon_{\mathrm{it}}\end{array}$

Value is the firm value calculated with the Tobins' $Q$ formula, $C_{i t}$ is the proportion of the independent board of commissioners, KRit is the age of the company calculated from the time of establishment to the year of research, $\mathrm{CSR}_{\mathrm{it}}$ is the disclosure of corporate social responsibility (CSR) that has been in the form of Corporate Social Responsibility Index (CSRI), ROA $\mathrm{it}_{\text {it }}$ is the return on assets of the company from ICMD, $\mathrm{LEV}_{\text {it }}$ is leverage, and $\mathrm{e}$ is the error term.

\section{FINDING AND DISCUSSION}

Table 1 presents the descriptive statistics for this research model. The results show that all variables used in this model have a reasonable degree of variation. For these research variables, Table 1 shows the mean values (Value ${ }_{i t}$ ) for the period 2014 to 2018 of $23,458,078$. As for corporate governance $\left(\mathrm{CG}_{\mathrm{it}}\right)$, corporate social responsibility $\left(\mathrm{CSR}_{\mathrm{it}}\right)$ disclosure and company characteristics $\left(\mathrm{KR}_{\mathrm{it}}\right)$ respectively have a mean of $0.43,0.53$, and $537,777,778$.

Table 1. Descriptive Statistics

\begin{tabular}{lllll}
\hline & Mean & Minimum & Maximum & Std. Dev. \\
\hline CGit & 0.43 & 0.00 & 0.80 & 0.15 \\
CSRit & 0.53 & 0.28 & 0.78 & 0.13 \\
KRit & 537.777 .778 & 2.300 .000 & 11.300 .000 & 2.471 .535 .836 \\
Valueit & 23.458 .078 & 0.36 & 2.328 .575 & 421.598 .836 \\
ROAit & 0.07 & -0.05 & 0.47 & 0.10 \\
LEVit & 0.58 & 0.13 & 0.91 & 0.25 \\
\hline
\end{tabular}

The Pearson and Spearman correlations between variables are calculated and presented in Table 2. The testing of correlation matrices is used for independent variables of this research model. Table 2 shows the absence of correlation coefficients above 0.8 , so there are no multicollinearity issues. Variance Inflation Factors (VIF) have been tested 
and the results are still within the acceptable limit of less than 10. Based on Table 2, it can be determined that the correlation between corporate social responsibility $\left(\mathrm{CSR}_{\mathrm{it}}\right)$ disclosure and company values $\left(\right.$ Value $_{\mathrm{it}}$ ) is positive and significant at the level of $1 \%$. Other than that, the correlation between the firm characteristics $\left(\mathrm{KR}_{\mathrm{it}}\right)$ and the firm values (Value $_{\mathrm{it}}$ ) is positive and significant at the level of $1 \%$, as well as for corporate governance $\left(\mathrm{CG}_{\mathrm{it}}\right)$ with the firm values $\left(\right.$ Value $\left._{\mathrm{it}}\right)$ is positive and significant at the level of $1 \%$. This is an early indication that corporate social responsibility (CSR) disclosure, corporate characteristic, and corporate governance are related to the firm values. More comprehensive testing will be done through regression analysis.

Table 2. Bivariate Correlation

\begin{tabular}{llllll}
\hline & CGit & CSRit & KRit & Nilaiit & ROAit \\
\hline CSRit & $-0.396^{* *}$ & & & & \\
KRit & $0.378^{* *}$ & 0.054 & & & \\
Valueit & $0.595^{* *}$ & 0.064 & $0.506^{* *}$ & & \\
ROAit & $0.368^{* *}$ & 0.164 & $0.280^{* *}$ & $0.839^{* *}$ & \\
LEVit & $0.594^{* *}$ & $-0.611^{* *}$ & $0.250^{*}$ & 0.036 & $-0.247^{*}$ \\
\hline
\end{tabular}

*, **. Correlation is significant at the 0.05 and 0.01 level (2-tailed).

Table 3. Regression Results

\begin{tabular}{|c|c|c|c|c|c|c|c|c|}
\hline & Model 1 & & Model 2 & & Model 3 & & Model 4 & \\
\hline & Coefficier & Sig & Coefficie & Sig & Coefficients & Sig & Coefficient & Sig \\
\hline (Intercept) & -4.097 & 0.000 & & 0.000 & -5.666 & 0.001 & -6.625 & 0.000 \\
\hline CGit & 8.668 & -4.078 & & & & & 8.228 & 0.000 \\
\hline CSRit & & 0.000 & & & 3.837 & 0.073 & 2.328 & 0.222 \\
\hline KRit & & & 0.040 & 0.000 & & & 0.034 & 0.000 \\
\hline ROAit & 31.575 & 0.000 & 35.026 & 0.000 & 38.565 & 0.000 & 28.789 & 0.000 \\
\hline LEVit & 0.638 & 0.617 & 2.972 & 0.001 & 5.460 & 0.000 & 0.418 & 0.748 \\
\hline
\end{tabular}

The results of regression analysis to determine the influence of independent variables on dependent variables in research model 1 , research model 2 , research model 3 , and research model 4 are in line with the research hypothesis presented in Table 3. Model 1 shows that $C G$ has a significant and positive effect on the firm value with a significance of less than 0.05 (sig=0.000 < $\alpha=0.05$ ), so hypothesis 1 is supported. Model 2 shows that KR has a significant and positive effect on firm value; since the significance value is less than 0.05 ( $\operatorname{sig}=0.000<\alpha=0.05$ ), hypothesis 2 is supported. Model 3 proves that CSR disclosure is positive to the firm value. However, it does not affect with significance values greater than 0.05 ( $\operatorname{sig}=0.073>\alpha=0.05$ ) which makes hypothesis 3 is unsupported. Model 4 is a simultaneous test of dependent variables proving that $C G$ and $K R$ variables have a significant and positive effect on the firm value, but CSR variables have no effect on the company's value with a significance of more than 0.05 (sig $=0.222>\alpha=0.05$ ). 
Hypothesis 1 states that good corporate governance will positively relate to the value of empirically supported companies. The better the corporate governance of a company, the better it will be able to increase the value of the company. The corporate governance increased by $1 \%$ followed by an increase in the firm value by $8.668 \%$. The results of hypothesis 1 are following the results of the research conducted by Retno \& Priantinah (2012) replicated by the authors. The results are also in line with previous researches by Herawaty (2008), Vira \& Wirakusuma (2019), and Wahyudi (2010). According to Rustiarini (2010), several things can cause corporate governance to affect the value of the company, namely: (1) high awareness of the company to implement corporate governance as a necessity, not only compliance with existing regulations, (2) the management of the company interested in the long-term benefits of the implementation of corporate governance, and (3) the existence of a board of commissioners in which there is an independent commissioner can monitor the company in implementing corporate governance.

Hypothesis 2 which states that the characteristics of the company will be positively related to the value of the company is supported empirically. This means that the longer the company is established, the more valuable the company will be. The company's

lifespan will increase by $1 \%$ accompanied by an increase in the firm value by $0.040 \%$. The characteristics of a mature company will make the company better value. This is in line with the research conducted by Ikhwandarti et al. (2010).

Hypothesis 3 which states that the disclosure of corporate social responsibility (CSR) in the sustainability report will positively relate to the firm value is not supported by empirical data. The regression coefficient represents a value of 3.837 with a significance of 0.073. The sign of this regression coefficient is positive. Positive values indicate that the disclosure of corporate social responsibility (CSR) in the sustainability report is a good thing done by the company. However, the disclosure of corporate social responsibility (CSR) in the sustainability report is not necessarily able to increase the value of the company. This is because no government regulation regulates the disclosure of corporate social responsibility (CSR) carried out by the company. Similarly, sustainability reports are voluntary additional reports made by companies. The results of this study are in line with Retno \& Priantinah (2012) replicated by the authors and research conducted by Vira $\&$ Wirakusuma (2019). The results of the study by Setyawan (2017) also showed that there is no influence of corporate social responsibility-free variables on variables tied to the firm value. This is because investors in Indonesia tend to buy and sell shares regardless of the company's long-term survival.

Hypothesis 4 which states that good corporate governance, corporate social responsibility (CSR) disclosure in sustainability reports, and firm characteristics will be positively related to the firm value is not supported by empirical data. This is because the factor that further affects the value of the company for investors is a good corporate governance and the firm characteristics that are getting older are increasingly valuable. While the disclosure of corporate social responsibility (CSR) is only another consideration used to understand the company's activities that have been done for either investors or 
creditors. Disclosure of corporate social responsibility (CSR) will have an impact on the future of the company rather than directly affect the firm values. Conversely, corporate governance is already a corporate obligation that must be done and contained in regulations or laws. The results of this research are different from those conducted by Rustiarini (2010) which means that investors in Indonesia have considered corporate social responsibility (CSR) reports in investment decision making. In addition, Margaretha \& Witedjo (2017) state that CSR actions implemented as a strategy will only cause irregularities in the use of funds owned by companies that can trigger damage to the company's financial performance. This is alleged because the budgeted funds are quite large with the implementation of CSR that is under-supervised, thus causing inefficiencies. The lack of supervision of CSR leads to misuse of funds used for opportunistic behavior by the implementers of the CSR program.

\section{CONCLUSION}

This research aims to investigate the effect of corporate governance, firm characteristics, corporate social responsibility (CSR) disclosure, and firm value. Based on empirical data of current research, the effect on the firm value is only good corporate governance and firm characteristics. Better corporate governance and stronger firm characteristics will be able to increase the firm value. Disclosure of corporate social responsibility (CSR) is a necessary value. Although the implementation of corporate governance and corporate social responsibility (CSR) disclosure are both aimed at optimizing the firm value for shareholders. It can also be interpreted that companies that have good corporate governance, solid firm characteristics, and disclose corporate social responsibility (CSR) in the sustainability report must have high firm value. However, corporate social responsibility (CSR) disclosure is still voluntary. The implementation of corporate social responsibility (CSR) that is still voluntary will be seen as a positive signal that provides its benefits for its stakeholders.

This study has limitations regarding all the samples which have been used. This is because there is still a few companies that have sustainability reports. Besides, the Sustainability Report Award (SRA) was followed by the company's initiative and there have been no other awards related to corporate social responsibility (CSR) involving the government. Further research can be developed by increasing the company's year on existing company data or seeking awards involving the government related to corporate social responsibility (CSR). Moreover, the government should also have started to issue clear regulations or laws regarding the implementation and disclosure of corporate social responsibility (CSR) to have uniformity and certainty.

\section{REFERENCES}

Arilaha, M. A. (2009). Corporate Governance dan Karakteristik Perusahaan Terhadap Kebijakan Dividen. Jurnal Keuangan Dan Perbankan, 13(3), 386-394. https://doi.org/10.26905/jkdp.v13i3.1087. 
da Silveira, A. D. M., \& Barros, L. A. B. de C. (2011). Corporate Governance Quality and Firm Value in Brazil. SSRN Electronic Journal. https://doi.org/10.2139/ssrn.923310.

Effendi, M. A. (2009). The Power of Good Corporate Governance: Teori dan Implementasi. Salemba Empat.

Fauziah, G., Irwanto, A. K., \& Syamsun, M. (2016). Pengaruh Pengungkapan Corporate Social Responsibility terhadap Nilai Perusahaan pada Indeks Saham LQ45. MANAJEMEN IKM: Jurnal Manajemen Pengembangan Industri Kecil Menengah, 11(1), 52-60. https://doi.org/10.29244/mikm.11.1.52-60.

Herawaty, V. (2008). Peran Praktek Corporate Governance Sebagai Moderating Variable dari Pengaruh Earnings Management Terhadap Nilai Perusahaan. Jurnal Akuntansi Dan Keuangan, 10(2), 97-108. https://doi.org/10.9744/jak.10.2.PP.\%2097-108.

Ikhwandarti, F., Pratolo, S., \& Suryanto, R. (2010). Pengaruh Karakteristik Perusahaan Terhadap Nilai Perusahaan dan Pengungkapan Informasi Sosial Sebagai Variabel Intervening. Jurnal Akuntansi Dan Investasi, 11(1), 1-15. https://journal.umy.ac.id/index.php/ai/article/view/1070.

Jensen, M. C., \& Meckling, W. H. (1976). Theory of The Firm: Managerial Behavior, Agency Costs and Ownership Structure. Journal of Financial Economics, 3, 305-360. https://doi.org/https://doi.org/10.1016/0304-405X(76)90026-X.

Latupono, S. S., \& Andayani, A. (2015). Pengaruh Corporate Social Responsibility terhadap Nilai Perusahaan: Good Corporate Governance Variable Moderating. Jurnal Ilmu Dan Riset AKuntansi, $4, \quad$ N0. 8. garuda.ristekbrin.go.id/documents/detail/523974.

Margaretha, F., \& Witedjo, C. G. (2017). Csr, Nilai Perusahaan Dan Kinerja Keuangan Perusahaan Pada Industri Pertambangan Dan Manufaktur Di Indonesia. Media Riset $\begin{array}{lllll}\text { Akuntansi, Auditing Dan } & \text { Informasi, }\end{array}$ https://doi.org/10.25105/mraai.v14i1.1754.

Masrifa, A. Y. A. (2012). Pengaruh Karakteristik Perusahaan Terhadap Nilai Perusahaan, Dengan Dividend Payout Ratio Sebagai Variabel Intervening Perusahaan Manufaktur Yang Terdaftar Pada Bursa Efek Indonesia Periode 2006-2010. 1-20. http://eprints.undip.ac.id/47539/.

Murwaningsari, E., Ekonomi, F., \& Trisakti, U. (2009). Hubungan Corporate Governance, Corporate Social Responsibilities dan Corporate Financial Performance Dalam Satu Continuum. Jurnal Akuntansi Dan Keuangan, 11(1), 30-41. https://doi.org/10.9744/jak.11.1.pp.30-41.

Permanasari, W. I. (2010). Pengaruh Kepemilikan Manajemen, Kepemilikan Institusional, Dan Corporate Social Responsibility Terhadap Nilai Perusahaan. http://eprints.undip.ac.id/22816/1/WIEN_IKA_PERMANASARI.PDF.

Putri, A. K., Sudarma, M., \& Purnomosidhi, B. (2016). Pengaruh Corporate Social Responsibility terhadap Nilai Perusahaan dengan Ukuran Perusahaan dan Jumlah Dewan Komisaris sebagai Variabel Pemoderasi (Studi pada Perusahaan Manufaktur yang terdaftar Bursa Efek Indonesia). Jurnal Aplikasi Manajemen, 14(2). 
https://doi.org/10.18202/jam23026332.14.2.16.

Putri, C. D. (2013). Pengaruh Corporate Governance Dan Karakteristik Perusahaan Terhadap Pengungkapan Tanggung Jawab Sosial Perusahaan Di Dalam Sustainability Report (Studi Empiris Perusahaan yang Terdaftar di BEI). Jurnal Akuntansi, 11 No. 3. http://ejournal.unp.ac.id/students/index.php/akt/article/view/691.

Retno, R. D., \& Priantinah, D. (2012). Pengaruh Good Corporate Governance Dan Pengungkapan Corporate Social Responsibility Terhadap Nilai Perusahaan (Studi Empiris Pada Perusahaan Yang Terdaftar Di Bursa Efek Indonesia Periode 20072010). Jurnal Nominal, 1(1), 84-103. https://doi.org/10.17509/jpak.v2i2.15464.

Rustiarini, N. I. W. (2010). Pengaruh Corporate Governance Pada Hubungan CSR dan Nilai Perusahaan. Simposium Nasional Akuntansi XIII, 11, 1-24. https://www.researchgate.net/publication/344854540_PENGARUH_CORPORAT E_GOVERNANCE_PADA_HUBUNGAN_CORPORATE_SOCIAL_RESPONSI BILITY_DAN_NILAI_PERUSAHAAN.

Sembiring, E. R. (2006). Karakteristik Perusahaan Dan Pengungkapan Tanggung Jawab Sosial: Study Empiris Pada Perusahaan Yang Tercatat Di Bursa Efek Jakarta. Maksi, 6(January). https://www.researchgate.net/publication/277877352_KARAKTERISTIK_PERUS AHAAN_DAN_PENGUNGKAPAN_TANGGUNG_JAWAB_SOSIAL_STUDY_ EMPIRIS_PADA_PERUSAHAAN_YANG_TERCATAT_DI_BURSA_EFEK_JA KARTA.

Setyawan, B. (2017). Pengaruh Corporate Social Responsibility Dan Good Corporate Governance. Keberanjutan, 2(No. $\quad 1), \quad 498-527$. https://doi.org/10.32493/keberlanjutan.v2i1.y2017.p498-527.

Solihin, I. (2011). Corporate Social Responsibility: From Charity to Sustainability. Salemba Empat.

Surya, I., \& Yustiavandana, I. (2006). Penerapan Good Corporate Governance: Mengesampingkan Hak-hak Istimewa Demi Kelangsungan Usaha. Kencana Prenada Media Group.

Untari, L. (2011). Effect On Company Characteristics Corporate Social Responsibility Disclosures In Corporate Annual Report Of Consumption Listed In Indonesia Stock Exchange. Semantic Scholar. https://www.semanticscholar.org/paper/EFFECT-ONCOMPANY-CHARACTERISTICS-CORPORATE-SOCIALUntari/906d03f734a62d89eab2b21d1c246b51b03e4440.

Vira, A. N., \& Wirakusuma, M. G. (2019). Pengaruh Pengungkapan Corporate Social Responsibility Pada Nilai Perusahaan Dengan Good Corporate Governance Sebagai $\begin{array}{llll}\text { Pemoderasi. E-Jurnal Akuntansi, } & 26, & \end{array}$ https://doi.org/10.24843/eja.2019.v26.i02.p17.

Wahyudi, J. (2010). Pengaruh Pengungkapan Good Corporate Governance, Ukuran Dewan Komisaris Dan Tingkat Cross-Directorship Dewan Terhadap Nilai 
Perusahaan.

Skripsi

Universitas

Diponegoro.

https://core.ac.uk/download/pdf/11719267.pdf.

Wibisono, Y. (2007). Membedah Konsep \& Aplikasi CSR. Fascho Publishing.

Widianto, H. S. (2011). Pengaruh Profitabilitas, Likuiditas, Leverage, Aktivitas, Ukuran Perusahaan, Dan Corporate Governance Terhadap Praktik Pengungkapan Sustainability Report (Studi Pada Perusahaan - Perusahaan yang Listed (Go-Public) di Bursa Efek Indonesia (BEI). Jurnal Akuntansi, 1-83. https://core.ac.uk/download/pdf/11726826.pdf.

Wulandari, A. A., Ramantha, I. W., \& Wirakusuma, M. G. (2016). Dampak Moderasi Profitabilitas Terhadap Pengaruh Corporate Social Responsibility pada Niai Perusahaan Manufaktur. E-Jurnal Ekonomi Dan Bisnis Universitas Udayana, 5(7), 18891918. https://ojs.unud.ac.id/index.php/EEB/article/view/18260. 